\title{
PERFORMANCE AND STRENGTH EVALUATION ON SELF COMPACTING CONCRETE BY PARTIAL REPLACEMENT OF FLYASH AND GLASS POWER
}

\author{
Er. B. Subhan Ramji $1^{1} \&$ Mr. D. Varun Eswar ${ }^{2}$
}

\begin{abstract}
Self-Compacting concrete (SCC) is a high-performance concrete that can flow under its own weight to completely fill the form work and self-consolidates without any mechanical vibration. Such concretes are an accelerate for the placement, to reduce the labour requirements needed for consolidation, finishing and eliminate environmental pollution. This will ensure that the concrete obtained has good flowability, self-compacting ability and other desired SCC properties. The European Federation of Producers and Applicators of Specialist Products for Structures (EFNARC) [2005] have also laid down certain guidelines for fresh properties of SCC.

Which can placed and compacted in to every corner of a formwork; purely means of its self-weight by eliminating the need of either external energy input from vibrators or any type of compacting effort. There is a current trend in all over the world to utilize the treated and untreated industrial by- products, domestic wastes etc., as raw materials in concrete. These not only help in reduce of the waste materials but also create a cleaner and greener environment.

In this study the main aim is to focus on the possibility of using industrial by product as a waste material in a preparation of innovative concrete. One kind of waste was identified as Glass Powder (GP) and another one is fly ash. The use of this Glass Powder and fly ash are the partial replacement of fine aggregate and cement was proposed in different percentage for production of self-compacting concrete. The experimental work deals with the ingredient of these mixtures (Glass powder, fly ash, super plasticizer, and cement) to improve the strength by examining their specific role in self-compacting concrete.

Keywords- Glass Powder (GP), Self-Compacting Concrete (SCC), Self-Compatibility, Compressive strength, Flexural strength.
\end{abstract}

\section{INTRODUCTION}

Concrete is a widely used construction material around the world, and its properties have been undergoing changes through technological advancement. Numerous types of concrete have been developed to enhance the different properties of concrete. So far, this development can be divided into four stages. The earliest is the traditional normal strength concrete which is composed of only four constituent materials, which are cement, water, fine and coarse aggregates. With a fast population growth and a higher demand for housing and infrastructure, accompanied by recent developments in Civil Engineering, such as high-rise buildings and long-span bridges, HIGH COMPRESSIVE strength concrete was needed.

The development of SELF-COMPACTING Concrete can be assumed to be the most important one into the building material's domain. This is due to the benefits that this concrete offers:

- The technology of producing self-compacting Concrete can be considered as an energy conservation process, since the electricity consumption for vibration it is eliminated; use of Self-Compacting Concretes increase the lifetime of the construction moulds, reduces the necessity of skilled workers.

- SCC can be used for all types of structures due to the fact that it can be pumped at long distances without any of its segregation.

- From the contractor's point of view, costly labour operations are avoided improving the efficiency of the building site.

- The concrete workers avoid poker vibration which is a huge benefit for their working environment.

- When vibration is omitted from casting operations the workers experience a less vigorous work with significant less noise and vibration exposure.

- Very good finishing surfaces of the elements made with Self-Compacting Concrete, which is a cut in remedial costs.

- SCC is believed to increase the durability relatively to vibrated concrete (this is due to the lack of damage to the internal structure, which is normally associated with vibration).Construction practice and performance, combined with the health and safety benefits, make SCC a very attractive solution for both precast concrete and civil engineering construction.

\footnotetext{
${ }^{1}$ Department of Civil Engineering, Pragati Engineering College, Surampalem, Andhra Pradesh, India.

${ }^{2}$ Department of Civil Engineering, Kakinada Institute of Engineering \& Technology, Korangi, Andhra Pradesh, India.
} 
- SCC has proved beneficial because of number of factors including faster construction, Reduction in site man power, better surface finishing, Improve durability, Easier placing, and Greater freedom in design, Reduce noise levels, and absence of vibration.

\section{OBJECTIVE}

1. Principally, to find test which identify the three key properties of SCC, for mix design purposes in the lab, and for compliance purposes on site.

2. To mention a range of results, for the chosen tests, which will enable non specialists to identify suitable SCC, and be considered for compliance in specifications.

3. To confirm the scientific basis of these tests by fundamental rheological measurements of the concrete.

4. To encourage the use of self-compacting concrete in general construction and to realize the potential and economical and environmental benefits of this technology.

5. To arrive at an appropriate mix design for self-compacting concrete and analyze their rheological properties.

6. To study the effect of glass powder on the durability parameters of SCC using fly ash.

7. To investigate the effect of dosages of blended admixture on compressive strength, split tensile strength and flexural strength of self-compacting concrete.

8. To determine the compressive strength, Split tensile strength and flexural strength of both conventional and selfcompacting concrete and compare their results.

\section{EXPERIMENTAL WORK}

Wide spread applications of SCC have been restricted due to lack of standard mix design procedure and testing methods. It is pertinent to mention that only features of SCC have been included in Indian Standard Code of practice for plain and reinforced concrete (fourth revision), [2000]. Slump flow test, L-box test, V-funnel test, U-box test, Orimet test \& GTM Screen test are recommended by EFNARC [European Federation of Producers and Applicators of Specialist Products for Structures, May 2005] for determining the properties of SCC in fresh state.

The experimental program consisted of casting and testing specimens for arrive the strength by partial replacement of fly ash and Glass Powder in place of cement. Different grade of concrete is considered in this study. In the first stage the Nan Su method of mix design [2001] was adopted to arrive at the suitable mix proportions. The mix designs were carried out for concrete grades 20,25, and 30. This method was preferred as it has the advantage of considering the strength of the SCC mix. The effectiveness will be arrived for different grade of concrete, based on the mechanical properties and fresh properties of SCC. Unlike other proportioning methods like the Okamura and EFNARC methods, it gives an indication of the target strength that will be obtained after 28days of curing.

The water to powder ratio was varied so as to obtain SCC mixes of various strengths. A total of 12 trial mixes were done by varying the proportions of water and powder within the calculated ranges. The details of the mixes are as in Table. All the ingredients were first mixed in dry condition. Then $70 \%$ of the calculated amount of water was to be added to the dry mix and mixed thoroughly. Then, $30 \%$ of water was mixed with the super-plasticizer and included in the mix. Then, the mix was checked for self-compatibility by flow test, V-funnel test and L-Box test.

\subsection{Materials -}

The materials used in the experimental investigation are locally available cement, sand, coarse aggregate, mineral and chemical admixtures. The chemicals used in the present investigation are of commercial grade. Cement Ordinary Portland cement of 53 grade [IS: 12269-1987, Specifications for 53 Grade Ordinary Portland cement] has been used in the study. It was procured from a single source and stored as per IS: 4032 - 1977. Care has been taken to ensure that the cement of same company and same grade is used throughout the investigation. The cement thus obtained was tested for physical properties in accordance with the IS: 12269 - 1987.

\subsection{Cement -}

Selection of the type of cement will depend on the overall requirements for the concrete, such as strength, durability, etc. C3 content higher than $10 \%$ may cause problems of poor workability retention.

- The typical content of cement is $350-450 \mathrm{Kg} / \mathrm{m}^{3}$.

- More than $500 \mathrm{Kg} / \mathrm{m}^{3}$ cement can be dangerous and increase the shrinkage.

- Less than $350 \mathrm{Kg} / \mathrm{m}^{3}$ May only is suitable with the inclusion of other fine filler, such as fly ash, pozzolana, glass powder etc.

Table 3.1 shows the physical characteristics of Ultra-Tech (53 Grade) cement used, tested in accordance with IS:40311988 [Methods of physical tests for hydraulic cement]. 
Table: 3.1 Physical properties of Ordinary Portland Cement

\begin{tabular}{|l|l|l|l|l|}
\hline S. No & Property & Test Method & Test Results & IS Standard \\
\hline 1. & $\begin{array}{l}\text { Normal } \\
\text { Consistency }\end{array}$ & $\begin{array}{l}\text { Vicat Apparatus } \\
\text { (IS:4031 Part-4) }\end{array}$ & $29.5 \%$ & \\
\hline 2. & Specific Gravity & Sp. Gr Bottle (IS:4031 Part-4) & 3.10 & \\
\hline 3. & Initial Setting Time & $\begin{array}{l}\text { Vicat Apparatus } \\
\text { (IS:4031 Part-4) }\end{array}$ & 53 minutes & Not less than 30 minutes \\
\cline { 2 - 5 } & Final Setting Time & 493 Minutes & Not less than 10 hours \\
\hline 4. & Fineness & $\begin{array}{l}\text { Sieve test on sieve no.9 } \\
\text { (IS: 4031 Part -1) }\end{array}$ & $5 \%$ & $10 \%$ \\
\hline 5. & Soundness & $\begin{array}{l}\text { Le-Chatlier method } \\
\text { (IS: 4031 Part-3) }\end{array}$ & $2 \mathrm{~mm}$ & Not more than 10mm \\
\hline
\end{tabular}

\subsection{Fine Aggregates -}

All normal concreting sands are suitable for SCC, both crushed or rounded sands can be used. Siliceous or calcareous sands can be used. The amount of fines less than $0.125 \mathrm{~mm}$ is to be considered as powder and is very important for the rheology of the SCC. A minimum amount of fines (arising from the binders and the sand) must be achieved to avoid segregation. The fine aggregate used was locally available river sand without any organic impurities and conforming to IS: 383 - 1970 [Methods of physical tests for hydraulic cement]. The fine aggregate was tested for its physical requirements such as gradation, fineness modulus, specific gravity and bulk density in accordance with IS: $2386-1963$.

\subsection{Coarse Aggregates -}

All types of aggregates are suitable. The normal maximum size is generally $16-20 \mathrm{~mm}$; however particle sizes up to $40 \mathrm{~mm}$ or more have been used in SCC. Consistency of grading is of vital importance. Regarding the characteristics of different types of aggregate, crushed aggregates tend to improve the strength because of the interlocking of the angular particles, whilst rounded aggregates improve the flow because of lower internal friction. The coarse aggregate chosen for SCC was typically round in shape, well graded and smaller in maximum size than that used for conventional concrete. The size of coarse aggregate used in self-compacting concrete was between $10 \mathrm{~mm}$ to $16 \mathrm{~mm}$. The rounded and smaller aggregate particles provide better flowability and deformability of concrete and also prevent segregation.

Table: 3.2 Physical properties of Coarse and Fine aggregate.

\begin{tabular}{|l|l|l|l|l|}
\hline S. No & Property & Method & Fine Aggregates & Coarse Aggregates \\
\hline 1. & Specific Gravity & $\begin{array}{l}\text { Pycnometer } \\
\text { IS:2386 Part3-1986 }\end{array}$ & 2.65 & 2.85 \\
\hline 2. & $\begin{array}{l}\text { Bulk Density } \\
\text { Loose } \\
\text { Compacted }\end{array}$ & IS:2386 Part 3-1986 & $\begin{array}{l}1428 \mathrm{~kg} / \mathrm{m}^{3} \\
1580 \mathrm{~kg} / \mathrm{m}^{3}\end{array}$ & $\begin{array}{l}1651 \mathrm{~kg} / \mathrm{m}^{3} \\
1896 \mathrm{~kg} / \mathrm{m}^{3}\end{array}$ \\
\hline 3. & Bulking & IS:2386 Part 3-1986 & $10 \%$ water & --- \\
\hline 4. & $\begin{array}{l}\text { Flakiness } \\
\text { Index }\end{array}$ & (IS:2386 Part 2-1963) & --- & $8.08 \%$ \\
\hline 5. & Elongation Index & (IS:2386 Part 2-1963) & --- & $0 \%$ \\
\hline 6. & $\begin{array}{l}\text { Fineness } \\
\text { Modulus }\end{array}$ & $\begin{array}{l}\text { Sieve Analysis (IS:2386 } \\
\text { Part 2-1963) }\end{array}$ & 3.18 & 6.04 \\
\hline
\end{tabular}

\subsection{Water -}

Water used for mixing and curing was potable water, which was free from any amounts of oils, acids, alkalis, sugar, salts and organic materials or other substances that may be deleterious to concrete or steel confirming to IS : 3025 - 1964 part22, part 23 and IS : 456 - 2000 [Code of practice for plain and reinforced concrete]. The $\mathrm{pH}$ value should not be less than 6 . The solids present were within the permissible limits as per clause 5.4 of IS: 456 - 2000.

\subsection{Admixture -}

The most important admixtures are the Super plasticizers (high range water reducers), used with a water reduction greater than 20\%. The use of a Viscosity modifying Admixture (VMA) gives more possible of controlling segregation when the amount of powder is limited. This admixture helps to provide very good homogeneity and reduces the tendency to segregation.

\subsection{Flyash -}

The particle sizes in fly ash vary from less than $1 \mu \mathrm{m}$ to more than $100 \mu \mathrm{m}$ with the typical particle size measuring less than 20 $\mu \mathrm{m}$. Their surface area is typically 300 to $500 \mathrm{~m} 2 / \mathrm{kg}$, although some fly ash can have surface areas as low as $200 \mathrm{~m} 2 / \mathrm{kg}$ and as high as $700 \mathrm{~m} 2 / \mathrm{kg}$. The relative density or specific gravity of fly ash generally ranges between 1.9 and 2.8 and the color is generally grey. The flowability of self-compacting concrete depends on the powder and paste cement. Hence, in order to 
increase the flowability, a mineral admixture such as fly ash has been used. The Normal Consistency of Fly Ash was found to be $43 \%$.

Fly ash used in this investigation was procured from Simhadri Super Thermal Power plant, Visakhapatnam, Andhra Pradesh, India. It confirms with grade I of IS: 3812 -1981. A typical oxide composition of Indian fly ash is shown in Table 3.3. The chemical composition and physical characteristics of fly ash used in the present investigation were given in Tables 3.4 and Table 3.5.

Table: 3.3 Typical Oxide Composition of Indian fly ash

\begin{tabular}{|l|l|l|}
\hline $\mathrm{S} . \mathrm{NO}$ & Characteristics & Percentage \\
\hline 1. & Silica, $\mathrm{SiO}_{2}$ & $49-67$ \\
\hline 2. & Alumina $\mathrm{Al}_{2} \mathrm{O}_{3}$ & $16-28$ \\
\hline 3. & Iron oxide $\mathrm{Fe}_{2} \mathrm{O}_{3}$ & $4-10$ \\
\hline 4. & Lime CaO & $0.7-3.6$ \\
\hline 5. & Magnesia $\mathrm{Mg} \mathrm{O}$ & $0.3-2.6$ \\
\hline 6. & Sulphar Trioxide $\mathrm{SO}_{3}$ & $0.1-2.1$ \\
\hline 7. & Loss on Ignition & $0.4-1.9$ \\
\hline 8. & Surface area $\mathrm{m}^{2} / \mathrm{kg}$ & $230-600$ \\
\hline
\end{tabular}

Table: 3.4 Chemical requirements of fly ash

\begin{tabular}{|l|l|l|l|}
\hline S.No & Characteristics & $\begin{array}{l}\text { Requirements }(\% \text { by } \\
\text { weight })\end{array}$ & $\begin{array}{l}\text { Fly Ash used }(\% \\
\text { by weight }\end{array}$ \\
\hline $1 . \quad$ & $\begin{array}{l}\text { Silicon dioxide }\left(\mathrm{SiO}_{2}\right)+\text { Aluminum oxide }\left(\mathrm{Al}_{2} \mathrm{O}_{3}\right)+\text { Iron } \\
\text { oxide }\left(\mathrm{Fe}_{2} \mathrm{O}_{3}\right)\end{array}$ & $70(\min )$ & 94.46 \\
\hline 2. & Silicon dioxide $\left(\mathrm{SiO}_{2}\right)$ & $35(\min )$ & 62.12 \\
\hline 3. & Magnesium $\mathrm{Oxide}(\mathrm{MgO})$ & $5(\max )$ & 0.49 \\
\hline 4. & Iron oxide $\left(\mathrm{Fe}_{2} \mathrm{O}_{3}\right)$ & $10(\max )$ & 6.48 \\
\hline 5. & Calcium oxide $(\mathrm{CaO})$ & $3.6(\max )$ & 1.28 \\
\hline 6. & Titanium oxide $(\mathrm{TiO})$ & $5(\max )$ & 1.8 \\
\hline 7. & Potassium oxide $\left(\mathrm{K}_{2} \mathrm{O}\right)$ & $400(\max )$ & 128 \\
\hline 8. & Total sulphur as sulphur trioxide $\left(\mathrm{SO}_{3}\right)$ & $2.75(\max )$ & 0.36 \\
\hline 9. & Available alkalies as sodium oxide $\left(\mathrm{Na}_{2} \mathrm{O}\right)$ & $1.5(\max )$ & 0.05 \\
\hline 10. & Phosphorous Pentaoxide $\left(\mathrm{P}_{4} \mathrm{O}_{10}\right)$ & $4(\max )$ & 0.4 \\
\hline 11. & Disodium oxide $\left(\mathrm{Na}_{2} \mathrm{O}\right)$ & $3(\max )$ & 0.28 \\
\hline 12. & Loss on ignition & $12(\max )$ & 0.30 \\
\hline 13. & Chlorides $(\mathrm{Cl})$ & $1(\max )$ & 0.009 \\
\hline
\end{tabular}

Table: 3.5 Physical requirements of fly ash

\begin{tabular}{|l|l|l|l|}
\hline S.No & Physical properties & Test value & $\begin{array}{l}\text { Specification limit as } \\
\text { per } \\
\text { (IS:3812-1981) }\end{array}$ \\
\hline 1 & Specific gravity & --- \\
\hline 2 & Specific surface $\left(\mathrm{cm}^{2} / \mathrm{gm}\right)$ & 2.55 & 3200 \\
\hline 3 & Limit reactivity $\left(\mathrm{Kg} / \mathrm{cm}^{2}\right)$ & 3850 & 40 \\
\hline \multirow{2}{*}{4} & $\begin{array}{l}\text { Compressive strength at } 28 \text { days as percentage of strength of } \\
\text { corresponding plain cement mortar cubes }\end{array}$ & 52.5 & Not less than $80 \%$ \\
\hline 5 & Soundness by Autoclave expansion & Nil & --- \\
\hline 4 & $\begin{array}{l}\text { Fineness by sieving } \\
\% \text { passing } 300 \mu\end{array}$ & 97.5 & --- \\
& $\%$ passing $150 \mu$ & 93.0 & --- \\
& $\%$ passing $75 \mu$ & 84.5 & --- \\
\hline
\end{tabular}

\subsection{Glass Powder (Gp)-}

The chemical compositions of soda-lime glass which is the most commonly used in containers are compared with fly ash and cement as shown in Table 4. The chemical compositions of glass do not vary significantly irrespective of different origins. The $\mathrm{SiO} 2$ and $(\mathrm{Na} 2 \mathrm{O}+\mathrm{K} 2 \mathrm{O})$ of glass are much higher than those of fly ash and cement. The total reactive component $(\mathrm{SiO} 2+$ $\mathrm{Al} 2 \mathrm{O} 3+\mathrm{Fe} 2 \mathrm{O} 3$ ) contents of glass and fly ash are about the same. Other main constituent contents are in the similar range to those of fly ash and cement. Glass has a potential to be used as a powder in SCC. The preferred fineness of addition for SCC is 
more than $70 \%$ of particle passing $0.063 \mathrm{~mm}$ fine glass powder was reported to contribute to Micro Structural Properties due to its filler effect pozzolanic reactivity the sulphate resistance/ penetration resistance and freeze / thaw of concrete was all improvement after incorporating $20-30 \%$ glass powder compare to those of fly ash.

Glass powder was obtained from Anand cement agencies Kakinada. The powder product consisted of angular and flaky particle shapes. The chemical composition and physical characteristics of Glass Powder used in the present investigation were given in Tables 3.6 and Table 3.7

Table: 3.6 Chemical requirements of Glass Powder

\begin{tabular}{|l|l|l|}
\hline S.No & Chemical Constituents & Percentage \\
\hline 1 & Silicon dioxide $\left(\mathrm{SiO}_{2}\right)$ & 70.22 \\
\hline 2 & Calcium oxide $(\mathrm{CaO})$ & 11.33 \\
\hline 3 & Magnesium Oxide $(\mathrm{MgO})$ & --- \\
\hline 4 & Aluminum oxide $\left(\mathrm{Al}_{2} \mathrm{O}_{3}\right)$ & 1.64 \\
\hline 5 & Iron oxide $\left(\mathrm{Fe}_{2} \mathrm{O}_{3}\right)$ & 0.52 \\
\hline 6 & Total sulphur as sulphur trioxide $\left(\mathrm{SO}_{3}\right)$ & 15.29 \\
\hline 7 & Potassium oxide $\left(\mathrm{K}_{2} \mathrm{O}\right)$ & --- \\
\hline 8 & Density & 2.42 \\
\hline 9 & Specific Surface Area & 133 \\
\hline
\end{tabular}

Table: 3.7 Physical requirements of Glass Powder

\begin{tabular}{|l|l|l|}
\hline S.No & Physical properties & Percentage \\
\hline 1 & Colour & white \\
\hline 2 & Specific Gravity & 2.11 \\
\hline
\end{tabular}

\subsection{Super Plasticizer -}

High range water reducing admixture called as super plasticizers are used for improving the flow or workability for lower water-cement ratios without sacrifice in the compressive strength. These admixtures when they disperse in cement agglomerates significantly decrease the viscosity of the paste by forming a thin film around the cement particles. In the present work, the admixture used was a super plasticizer based on modified polycarboxylates, with a density of $1.08 \mathrm{~kg} / \mathrm{l}$ and a solids content of $32.5 \%$.

Table: 3.8 Physical requirements of Super Plasticizer

\begin{tabular}{|l|l|l|}
\hline S.No & Characteristics & Test value \\
\hline 1. & Chloride content & Nil \\
\hline 2. & Specific Gravity & 1.26 at $30^{\circ} \mathrm{C}$ \\
\hline 3. & Solid content & $40 \%$ \\
\hline 4. & Nature Liquid & --- \\
\hline
\end{tabular}

\subsection{Viscosity Modifying Agent -}

These admixtures enhance the viscosity of water and eliminate the bleeding and segregation phenomena in the fresh concrete as much as possible. VMA is a neutral, biodegradable, liquid chemical additive designed to reduce the bleeding, segregation, shrinkage and cracking that occur in high water/cement ratio concrete mixes. VMA also contribute to stabilization for SCC mixes that are susceptible to segregation at high slump ranges. The VMA used in this investigation was Glenium stream-2 which is a product of BASF construction chemicals. The properties of VMA are given in Table 3.9.

Table: 3.9 Details of Viscosity Modifying Agent

\begin{tabular}{|c|c|c|}
\hline S.No & Property & Result \\
\hline 1. & Aspect & Colourless free flowing liquid \\
\hline 2. & Relative density & 1.01 \\
\hline 3. & $\mathrm{PH}$ & $\geq 6$ \\
\hline 4. & $\begin{array}{l}\text { Chloride ion } \\
\text { content }\end{array}$ & $<0.2 \%$ \\
\hline 5. & Compatibility & Can be used with all types of cements \\
\hline 6. & Incompatible & Use with naphthalene sulphonate based super plasticiser admixtures. \\
\hline 7. & $\begin{array}{l}\text { Mechanism of } \\
\text { action }\end{array}$ & $\begin{array}{l}\text { It consists of a mixture of water soluble copolymers which is } \\
\text { adsorbed onto the surface of the cement granules, thereby } \\
\text { changing the viscosity of the water and influencing the rheological }\end{array}$ \\
\hline
\end{tabular}




\begin{tabular}{|l|l|c|}
\hline & & properties of the mix. \\
\hline 8. & Dosage & 50 o $500 \mathrm{ml} / 100 \mathrm{~kg}$ of cementitious material. \\
\hline
\end{tabular}

\subsection{Mix Proportioning -}

In designing the SCC mix, it is most useful to consider the relative proportions of the key components by volume rather than by mass. The following key proportions for the mixes listed below: Air content; Coarse aggregate content; Paste content; Binder (cementitious) content; Replacement of mineral admixture by percentage; Water/ binder ratio; Volume of fine aggregate/ volume of mortar; SP dosage by percentage cementitious; VMA dosage by percentage cementitious. The mix proportioning was done based on the Nan Su approach [2001]. The Mix Design types with percentage relative proportions and mix proportions of constituent materials are given in Table 4.1.

Table 4.1 Mix Proportion and Quantities of M20, M25, and M30 grade of SCC

\begin{tabular}{|c|c|c|c|c|c|c|c|c|c|c|}
\hline Grade & Mix & $\mathrm{W} / \mathrm{P}$ & $\begin{array}{l}\text { Water } \\
\left(\mathrm{Kg} / \mathrm{m}^{3}\right)\end{array}$ & $\begin{array}{l}\text { Cement } \\
\left(\mathrm{Kg} / \mathrm{m}^{3}\right)\end{array}$ & $\begin{array}{l}\mathrm{GP} \\
\left(\mathrm{Kg} / \mathrm{m}^{3}\right)\end{array}$ & $\begin{array}{l}\text { GP } \\
(\%)\end{array}$ & $\begin{array}{l}\text { Fly ash } \\
\left(\mathrm{Kg} / \mathrm{m}^{3}\right)\end{array}$ & $\begin{array}{l}\text { FA } \\
\left(\mathrm{Kg} / \mathrm{m}^{3}\right)\end{array}$ & $\begin{array}{l}\mathrm{CA} \\
\left(\mathrm{Kg} / \mathrm{m}^{3}\right)\end{array}$ & $\begin{array}{l}\text { SP } \\
(\%)\end{array}$ \\
\hline \multirow{4}{*}{ M20 } & Trial -1 & \multirow{4}{*}{0.46} & \multirow{4}{*}{216.2} & 470 & 0 & 0 & 94 & 705 & 1410 & 0.846 \\
\hline & Trial -2 & & & 473 & 23.5 & 5 & 94 & 705 & 1410 & 0.846 \\
\hline & Trial -3 & & & 470 & 47.0 & 10 & 94 & 705 & 1410 & 0.846 \\
\hline & Trial -4 & & & 472 & 70.5 & 15 & 94 & 705 & 1410 & 0.846 \\
\hline \multirow{4}{*}{ M25 } & Trial -1 & \multirow{4}{*}{0.42} & \multirow{4}{*}{205.8} & 490 & 0 & 0 & 98 & 612.5 & 980 & 0.882 \\
\hline & Trial -2 & & & 492 & 24.5 & 5 & 98 & 612.5 & 980 & 0.882 \\
\hline & Trial -3 & & & 490 & 49 & 10 & 98 & 612.5 & 980 & 0.882 \\
\hline & Trial -4 & & & 493 & 73.5 & 15 & 98 & 612.5 & 980 & 0.882 \\
\hline \multirow{4}{*}{ M30 } & Trial -1 & \multirow{4}{*}{0.38} & \multirow{4}{*}{193.8} & 510 & 0 & 0 & 102 & 795.6 & 637.5 & 0.918 \\
\hline & Trial -2 & & & 512 & 25.5 & 5 & 102 & 795.6 & 637.5 & 0.918 \\
\hline & Trial -3 & & & 510 & 51 & 10 & 102 & 795.6 & 637.5 & 0.918 \\
\hline & Trial -4 & & & 511 & 76.5 & 15 & 102 & 795.6 & 637.5 & 0.918 \\
\hline
\end{tabular}

3.12 Fresh Properties Of Scc-

The details of the fresh properties are shown in Table 4.2, for M20, M25, and M30 grade concrete.

Table: 4.2 Fresh properties of for M20, M25, and M30 grade concrete

\begin{tabular}{|c|c|c|c|c|c|c|c|}
\hline S. No & Grade & MIX & $\begin{array}{l}\text { Slump Flow } \\
\text { value }\end{array}$ & $\mathbf{T}_{50}$ & V-Funnel & $\begin{array}{l}\text { V-Funnel } \\
\text { At } T_{5} \text { Minutes }\end{array}$ & $\begin{array}{l}\text { L-Box H2/H1 } \\
\text { (blocking ratio) }\end{array}$ \\
\hline \multirow{4}{*}{1.} & \multirow{4}{*}{ M20 } & Trial -1 & 720 & $5 \mathrm{sec}$ & $8.6 \mathrm{sec}$ & $12 \mathrm{sec}$ & 0.90 \\
\hline & & Trial -2 & 710 & $4 \mathrm{sec}$ & $8.9 \mathrm{sec}$ & $11 \mathrm{sec}$ & 0.88 \\
\hline & & Trial -3 & 705 & $5 \mathrm{sec}$ & $9.7 \mathrm{sec}$ & $12 \mathrm{sec}$ & 0.80 \\
\hline & & Trial -4 & 685 & $5 \mathrm{sec}$ & $10.8 \mathrm{sec}$ & $12 \mathrm{sec}$ & 0.87 \\
\hline \multirow{4}{*}{2.} & \multirow{4}{*}{ M25 } & Trial -1 & 715 & $5 \mathrm{sec}$ & $8.8 \mathrm{sec}$ & $8 \mathrm{sec}$ & 0.85 \\
\hline & & Trial -2 & 707 & $5 \mathrm{sec}$ & $9.5 \mathrm{sec}$ & $9 \mathrm{sec}$ & 0.97 \\
\hline & & Trial -3 & 697 & $4 \mathrm{sec}$ & $10.6 \mathrm{sec}$ & $8 \mathrm{sec}$ & 0.95 \\
\hline & & Trial -4 & 675 & $5 \mathrm{sec}$ & $11.6 \mathrm{sec}$ & $8 \mathrm{sec}$ & 0.91 \\
\hline \multirow{4}{*}{3.} & \multirow{4}{*}{ M30 } & Trial -1 & 710 & $5 \mathrm{sec}$ & $9.3 \mathrm{sec}$ & $9 \mathrm{sec}$ & 0.97 \\
\hline & & Trial -2 & 700 & $5 \mathrm{sec}$ & $10.1 \mathrm{sec}$ & $9 \mathrm{sec}$ & 0.92 \\
\hline & & Trial -3 & 688 & $4 \mathrm{sec}$ & $11.2 \mathrm{sec}$ & $8 \mathrm{sec}$ & 0.91 \\
\hline & & Trial -4 & 670 & $5 \mathrm{sec}$ & $11.7 \mathrm{sec}$ & $9 \mathrm{sec}$ & 0.94 \\
\hline
\end{tabular}

\section{EXPERIMENTAL RESULT}

4.1 Experimental Results Obtained:

4.1.1 Mix Design Procedure by Nam-Su Method-

The design mix is carried out by the specified method by NAN-SU Scientist in Japan. The principal consideration of the proposed method is to fill the paste of binders into voids of the aggregate framework piled loosely. The volume ratio of aggregate is about $52-58 \%$, in other words, the void in the loose aggregate is about $42-48 \%$ according to ASTM C29.

The procedures of the proposed mix design method can be summarized in the following steps.

Step 1: Calculation of coarse and fine aggregate contents.

Step 2: Calculation of cement content.

Step 3: Calculation of mixing water content required by cement.

Step 4: Calculation of fly ash (FA) and Glass Powder (GP) contents.

Step 5: Calculation of mixing water content needed in SCC. 
Step 6: Calculation of SP dosage.

Step 7: Adjustment of mixing water content needed in SCC.

Step 8: Trial mixes and tests on SCC properties.

Step 9: Adjustment of mix proportions.

\subsubsection{Batching of ingredients -}

The various ingredients required for SCC mix were taken by weight batching.

\subsubsection{Mixing of ingredients -}

All the ingredients taken by weigh batching are separately sorted out. First of all coarse aggregate is spread up in the large tray. In separate tray fine aggregate, cement and fly ash are mixed in dry condition. This mixed material is then spread up over coarse aggregate and then complete ingredient is mixed in dry conditions. After that make a hole at center of the mixed material then $70 \%$ of the required quantity of water as per adopted water cement ratio is added and material is mixed and remaining $30 \%$ water is added. Mixing is continued till the concrete mix attained uniform colour and consistency.

\subsubsection{Preparation / Curing / Testing of cubes -}

At a time 3 cubes are casted in the laboratory of size $15 \mathrm{~cm}$ x $15 \mathrm{~cm}$ x $15 \mathrm{~cm}$. The casting of cubes is done as follows First of all the moulds used for casting purpose are oiled from inside so that the concrete does not stick to the surface. Then nuts and bolts of mould are checked, whether they are well tightened or not. Immediately after mixing, the concrete is filled in mould. Like this moulds cubes are filled. The prepared cubes are kept as such as a temperature of $270 \mathrm{C}+20 \mathrm{C}$ in an atmosphere of at least $90 \%$ relative humidity for $24 \mathrm{hrs}$. From the time of addition of water to dry ingredients. At the end of this period concrete cubes are taken out of mould for curing purpose the method of curing by pounding. In this method after taking out cubes from the moulds they are immediately submerged in clean and fresh water for curing and kept for specific period till they are taken out for testing purpose. These cubes were removed turn by turn and the compressive strength was tested after $7 \& 28$ days of curing of each set of cubes the compressive strength of cubes was tested in compressive testing machine.

\subsubsection{Preparation / Curing / Testing of cylinders -}

At a time 3 cylinders are casted in the laboratory of size $(150 \mathrm{~mm}$ dia $\times 300 \mathrm{~mm}$ height). The casting of cylinders is done as follows First of all the moulds used for casting purpose are oiled from inside so that the concrete does not stick to the surface. Then nuts and bolts of mould are checked, whether they are well tightened or not. Immediately after mixing, the concrete is filled in mould. The prepared cylinders are kept as such as a temperature of $270 \mathrm{C}+20 \mathrm{C}$ in an atmosphere of at least $90 \%$ relative humidity for $24 \mathrm{hrs}$. From the time of addition of water to dry ingredients. At the end of this period concrete cylinders are taken out of mould for curing purpose the method of curing by pounding. In this method after taking out cylinders from the moulds they are immediately submerged in clean and fresh water for curing and kept for specific period till they are taken out for testing purpose. These cylinders were removed turn by turn and the split tensile strength was tested after $7,14 \& 28$ days of curing of each set of cylinders the split tensile strength of cylinders was tested in split tensile testing machine.

\subsubsection{Preparation / Curing / Testing of beams -}

At a time 2 beams are casted in the laboratory of size $10 \mathrm{~cm}$ x $10 \mathrm{~cm}$ x $50 \mathrm{~cm}$. The casting of beams is done as follows. First of all the moulds used for casting purpose are oiled from inside so that the concrete does not stick to the surface. Then nuts and bolts of beams mould are checked, whether they are well tightened or not. Immediately after mixing, the concrete is filled in mould. The prepared beams are kept as such as a temperature of $270 \mathrm{C}+20 \mathrm{C}$ in an atmosphere of at least $90 \%$ relative humidity for $24 \mathrm{hrs}$. From the time of addition of water to dry ingredients. At the end of this period concrete beams are taken out of mould for curing purpose the method of curing by pounding. In this method after taking out beams from the moulds they are immediately submerged in clean and fresh water for curing and kept for specific period till they are taken out for testing purpose. These beams were removed turn by turn and the flexural strength was tested after $7,14 \& 28$ days of curing of each set of beams the flexural strength of beams was tested in universal testing machine.

\subsection{The Mechanical Properties Obtained Based On The Specimens Tested Results:}

\subsubsection{Compressive strength:}

The results of the mechanical properties obtained based on the specimens tested as per Indian standard test procedures (as per IS: 516) are discussed. The M20, M25 and M30 grades of concrete cubes are casted and the different ages of curing are the variables of investigation. 


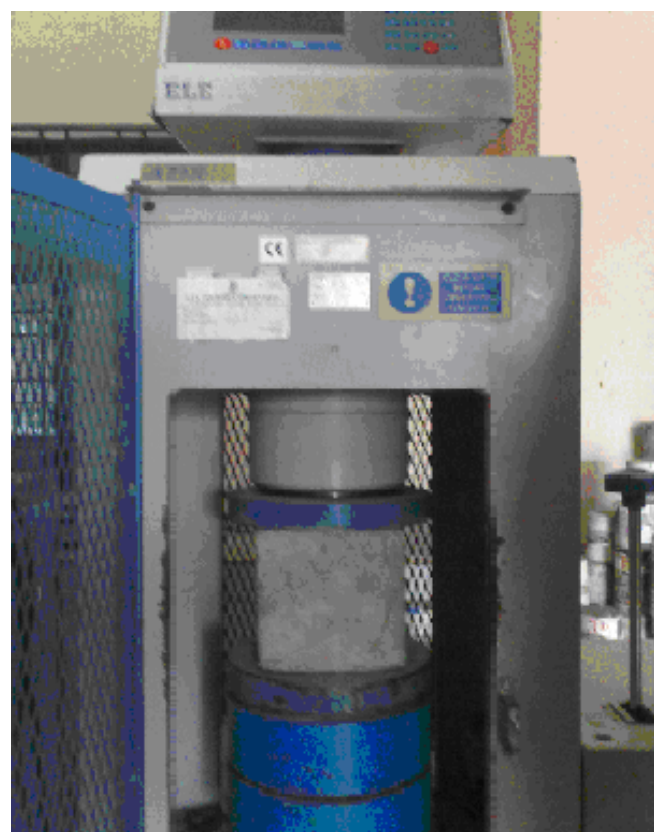

Fig.3.7 Compressive strength test setup

Table: 4.3 Compressive strength of M20, M25, and M30 grade SCC

\begin{tabular}{|l|l|l|l|l|l|}
\hline \multirow{3}{*}{ MIX } & \multirow{2}{*}{$\begin{array}{l}\text { FLYASH } \\
(\%)\end{array}$} & \multirow{2}{*}{$\begin{array}{l}\text { GLASS POWDER } \\
(\%)\end{array}$} & & \multicolumn{4}{l}{$\begin{array}{l}\text { COMPRESSIVE STRENGTH } \\
(\text { Mpa })\end{array}$} \\
\cline { 3 - 6 } & 20 & 0 & 7 Days & 14 Days & 28 Days \\
\cline { 2 - 6 } & 20 & 5 & 18.73 & 22.725 & 35.2 \\
\cline { 2 - 6 } & 20 & 10 & 19.56 & 23.395 & 38.54 \\
\cline { 2 - 6 } & 20 & 15 & 21.22 & 25.07 & 42.12 \\
\hline \multirow{4}{*}{ M20 } & 20 & 0 & 24.12 & 32.84 & 45.65 \\
\cline { 2 - 6 } & 20 & 10 & 21.96 & 26.89 & 40.65 \\
\cline { 2 - 6 } & 20 & 15 & 22.6 & 27.54 & 42.58 \\
\cline { 2 - 6 } & 20 & 0 & 23.41 & 36.15 & 46.12 \\
\hline \multirow{4}{*}{ M30 } & 20 & 5 & 26.84 & 41.56 & 50.26 \\
\cline { 2 - 6 } & 20 & 10 & 26.44 & 32.395 & 45.48 \\
\cline { 2 - 6 } & 20 & 15 & 27.2 & 33.335 & 48.65 \\
\cline { 2 - 6 } & 20 & & 28.14 & 42.45 & 52.45 \\
\hline
\end{tabular}

\subsubsection{Split tensile strength:}

This is also sometimes referred as "Brazilian Test" as this test was developed in Brazil in 1943. This comes under indirect tension test methods. The test was carried out by placing a cylindrical specimen horizontally between the loading faces of a compression testing machine and the load was applied until failure of the cylinder, along the vertical diameter as shown in Fig.3.10. A concrete cylinder of size $150 \mathrm{~mm}$ diameter and $300 \mathrm{~mm}$ height was subjected to the action of a compressive force along two opposite edges. The cylinder was subjected to compression near the loaded region and the length of cylinder is subjected to uniform tensile stress.

Horizontal tensile stress $=2 \mathrm{P} / \Pi \mathrm{D} \mathrm{L}$

Where $\mathrm{P}=$ Compressive load on the cylinder; $\mathrm{L}=$ Length of cylinder; $\mathrm{D}=$ Diameter of cylinder.

In the present investigation, the split tensile strength test has been conducted on concrete with different M20, M25 and M30 grade of SCC at 7, 14 and 28 days. 


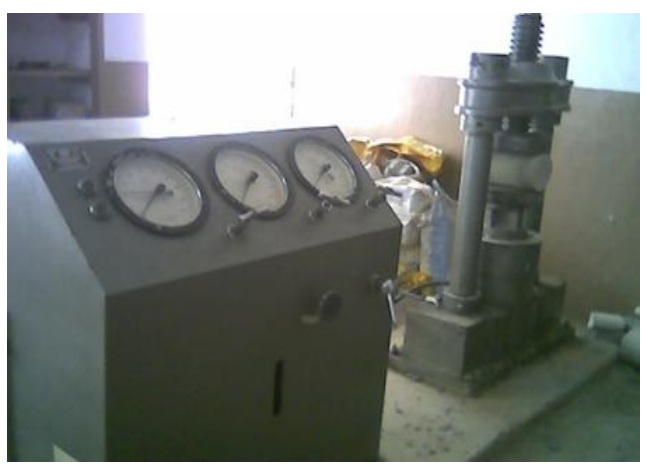

Fig.3.10 split tensile strength test

Table: 4.4 Split tensile strength of M20, M25, and M30 grade of SCC

\begin{tabular}{|l|l|l|l|l|l|}
\hline \multirow{3}{*}{ MIX } & \multirow{2}{*}{$\begin{array}{l}\text { FLYASH } \\
(\%)\end{array}$} & \multirow{2}{*}{$\begin{array}{l}\text { GLASS POWDER } \\
(\%)\end{array}$} & & \multicolumn{3}{l}{$\begin{array}{l}\text { Split tensile strength } \\
(\text { Mpa })\end{array}$} \\
\cline { 3 - 6 } & 20 & 0 & 7 Days & 14 Days & 28 Days \\
\hline \multirow{4}{*}{ M20 } & 20 & 5 & 1.4 & 4.275 & 7.15 \\
\cline { 2 - 6 } & 20 & 10 & 1.62 & 4.415 & 7.21 \\
\cline { 2 - 6 } & 20 & 15 & 1.91 & 4.625 & 7.34 \\
\hline \multirow{4}{*}{ M25 } & 20 & 0 & 2.10 & 4.782 & 7.42 \\
\cline { 2 - 6 } & 20 & 5 & 1.8 & 4.56 & 7.32 \\
\cline { 2 - 6 } & 20 & 10 & 2.05 & 4.74 & 7.43 \\
\cline { 2 - 6 } & 20 & 15 & 2.12 & 4.84 & 7.56 \\
\hline \multirow{4}{*}{ M30 } & 20 & 0 & 2.30 & 4.925 & 7.68 \\
\cline { 2 - 6 } & 20 & 10 & 2.24 & 4.945 & 7.65 \\
\cline { 2 - 6 } & 20 & 15 & 2.31 & 5.01 & 7.71 \\
\cline { 2 - 6 } & 20 & & 2.39 & 5.115 & 7.84 \\
\hline
\end{tabular}

\subsubsection{Flexural strength:}

Standard beam test (Modulus of rupture) was carried out on the beams of size $100 \mathrm{~mm}$ x $100 \mathrm{~mm}$ x $500 \mathrm{~mm}$ as per IS: 516 [Method of test for strength of concrete], by considering that material is homogeneous. The beams were tested on a span of $400 \mathrm{~mm}$ for $100 \mathrm{~mm}$ specimen by applying two equal loads placed at third points. To get these loads, a central point load has applied on a beam supported on steel rollers placed at third point as shown in Fig.3.8. The rate of loading is $1.8 \mathrm{KN} / \mathrm{minute}$ for $100 \mathrm{~mm}$ specimens and the load was increased until the beam failed. Depending on the type of failure, appearance of fracture and fracture load, the flexural tensile strength of the sample was estimated. As explained earlier, in the present investigation, the flexural strength test has been conducted on concretes with different M20, M25 and M30 grade of SCC at 7,14 and 28 days.

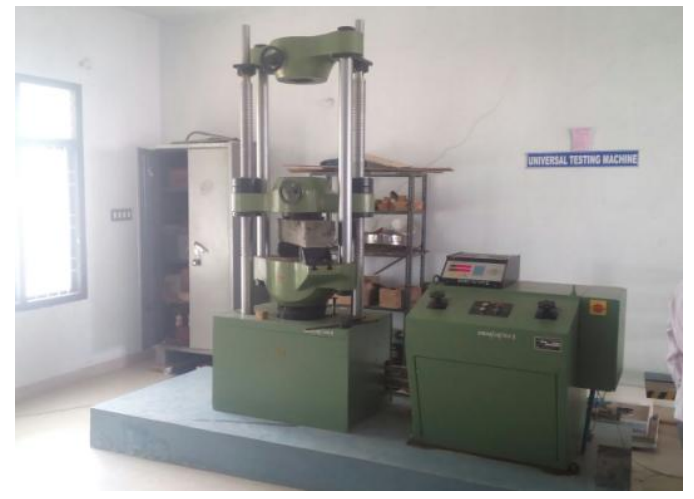

Fig.3.9 Flexural strength test 
Table: 4.5 Flexural strength of M20, M25, and M30 grade of SCC

\begin{tabular}{|l|l|l|l|l|l|}
\hline \multirow{3}{*}{ MIX } & \multirow{2}{*}{$\begin{array}{l}\text { FLYASH } \\
(\%)\end{array}$} & \multirow{2}{*}{$\begin{array}{l}\text { GLASS POWDER } \\
(\%)\end{array}$} & & \multicolumn{4}{l}{$\begin{array}{l}\text { Flexural strength } \\
(\text { Mpa })\end{array}$} \\
\cline { 3 - 6 } & 20 & 0 & 7 Days & 14 Days & 28 Days \\
\hline \multirow{4}{*}{ M20 } & 20 & 5 & 3.92 & 5.86 & 7.8 \\
\cline { 2 - 6 } & 20 & 10 & 4.15 & 6.1 & 8.05 \\
\cline { 2 - 6 } & 20 & 15 & 4.32 & 6.265 & 8.21 \\
\hline \multirow{4}{*}{ M25 } & 20 & 0 & 4.42 & 6.32 & 8.35 \\
\cline { 2 - 6 } & 20 & 5 & 4.41 & 6.63 & 8.85 \\
\cline { 2 - 6 } & 20 & 10 & 4.68 & 6.88 & 9.08 \\
\cline { 2 - 6 } & 20 & 15 & 4.82 & 7 & 9.18 \\
\hline \multirow{4}{*}{ M30 } & 20 & 0 & 4.92 & 7.10 & 9.28 \\
\cline { 2 - 6 } & 20 & 10 & 5.12 & 7.13 & 9.14 \\
\cline { 2 - 6 } & 20 & 15 & 5.28 & 7.255 & 9.23 \\
\cline { 2 - 6 } & 20 & & 5.36 & 7.355 & 9.35 \\
\hline
\end{tabular}

\section{DISCUSSION OF TEST RESULTS}

5.1 Compressive strength:

Table: 4.3 shows the details of the Compressive strength for partial replacement 5\%, 10\%, and 15\% of Glass powder and constant replacement $20 \%$ of fly ash for M20, M25, and M30 grades of concrete.

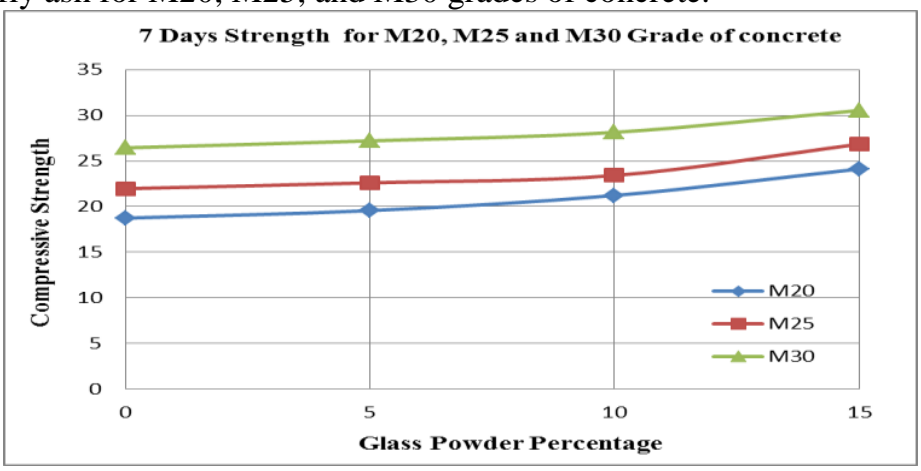

Fig 4.1: 7 Days of Compressive strength for different Grades of Concrete

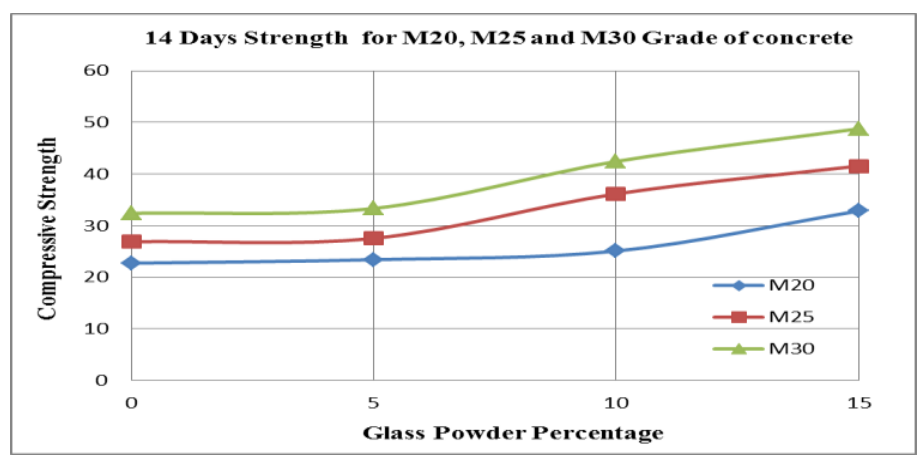

Fig 4.2: 14 Days Compressive strength for different Grades of Concrete 


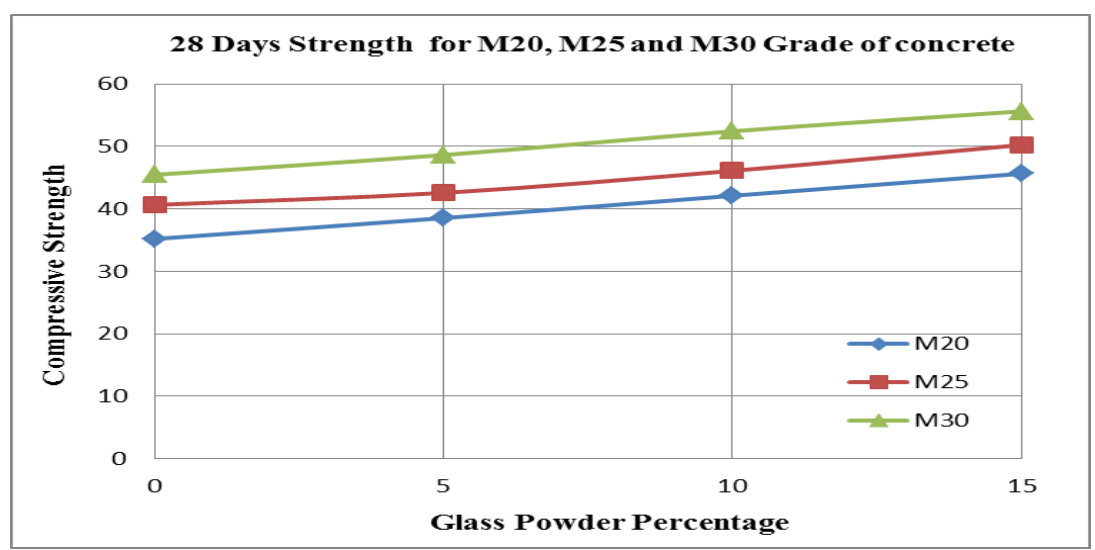

Fig 4.3: 28 Days Compressive strength for different Grades of Concrete

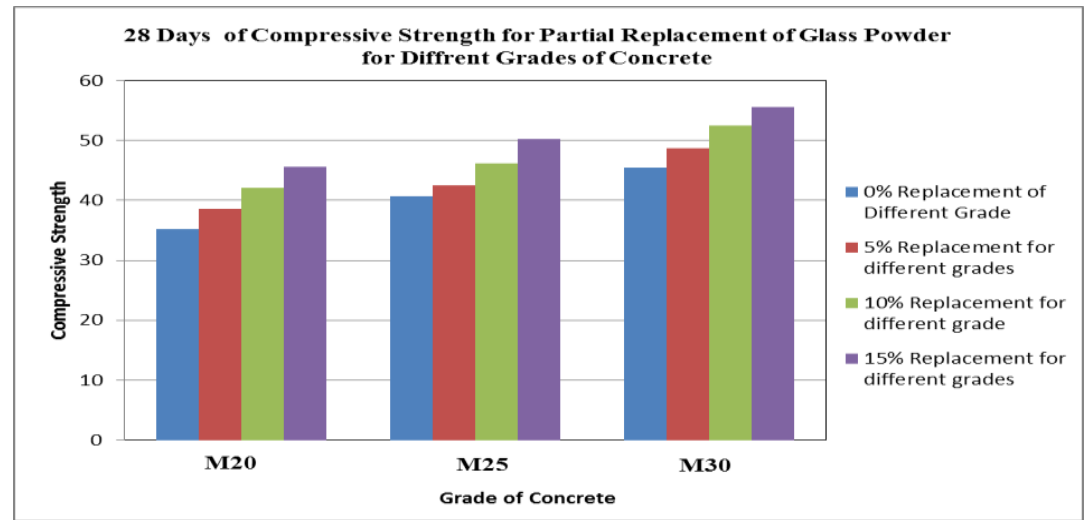

Fig 4.4: Bar Diagram for 28 Days Compressive strength for partial replacement of GP \& FA for different Grades of Concrete.

\subsection{Split tensile strength:}

Table 4.4 shows the details of the split tensile strength of different grade of concrete. A similar trend as that of compressive strength was noted with regard to the strength criteria.

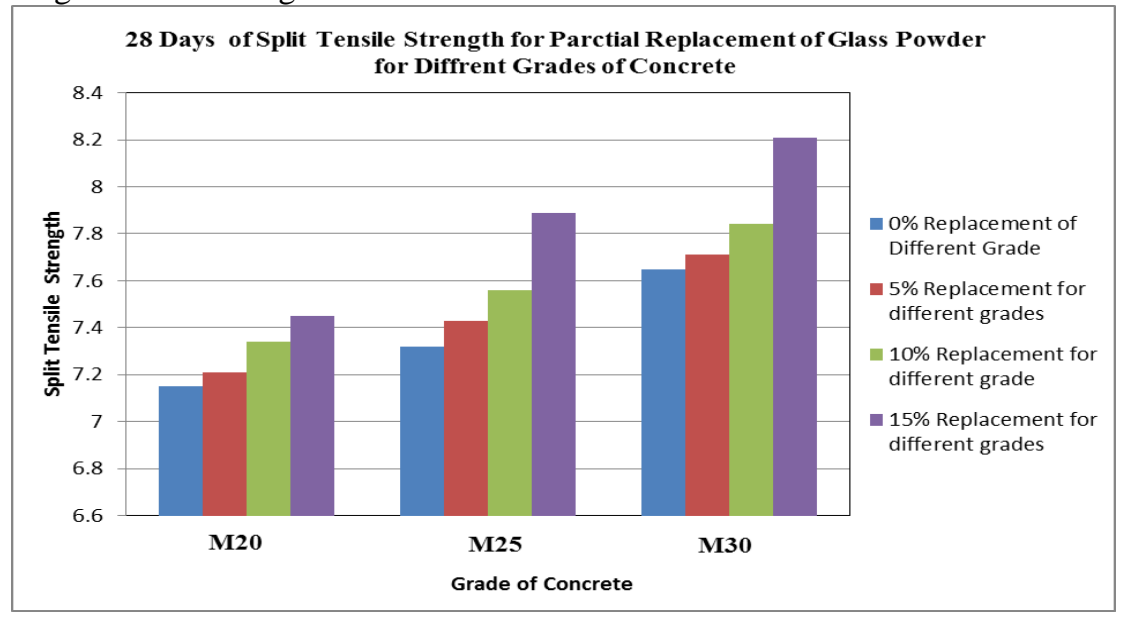

Fig 4.5: Bar Diagram for 28 Days Split Tensile strength for partial replacement of GP \& FA for different Grades of Concrete.

\subsection{Flexural strength:}

Table 4.5 shows the details of the flexural strength for partial replacement $5 \%, 10 \%$, and $15 \%$ of Glass powder and constant replacement $20 \%$ of fly ash for M20, M25, and M30 grades of concrete. 


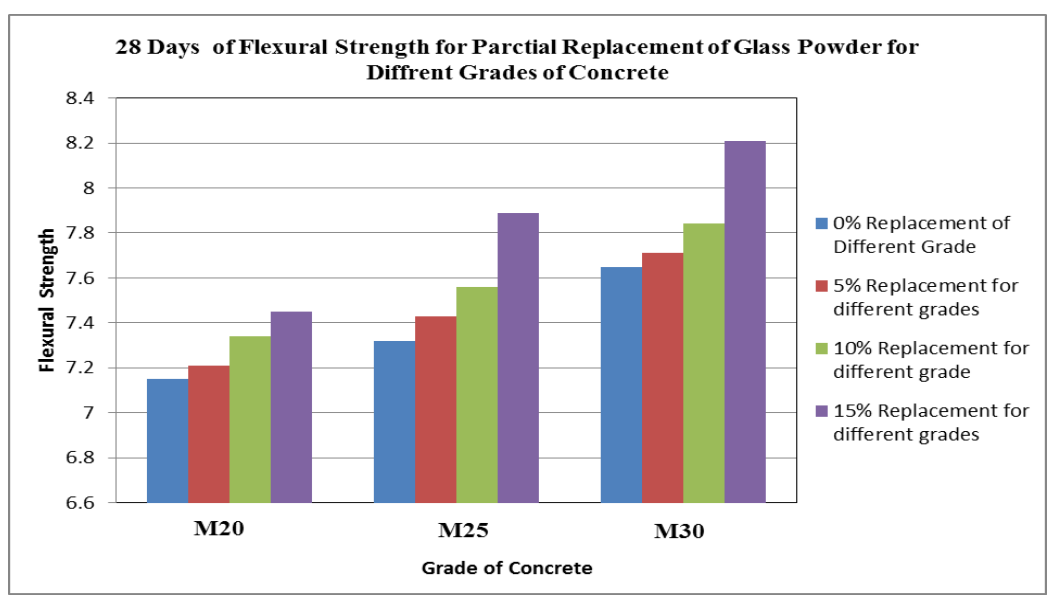

Fig 4.6: Bar Diagram for 28 Days Flexural strength for partial replacement of GP \& FA for different Grades of Concrete.

\section{CONCLUSIONS}

The latest researches are concentrating on ways to create new concrete by using various industrial wastes. The addition of glass powder into concrete was a step that was taken to utilize glass powder obtained from the waste glass factory in an effective manner. Various properties of the glass powder integrated SCC mixes such as self-compatibility, compressive strength, and flexural strength were evaluated and compared with those of conventional SCC.

Based on the systematic and detailed experimental investigations conducted on SCC mixes with an aim to develop performance mixes, the following conclusions were arrived at:

1. The addition of glass powder in SCC mixes reduces the self-compatibility characteristics like filling ability, passing ability and segregation resistance.

2. The flow value increase by an average of $1.30 \%, 2.5 \%$ and $5.36 \%$ for glass powder replacements of $5 \%, 10 \%$ and $15 \%$ respectively.

3. The V-funnel time was observed to increase by an average of $6.21 \%, 15 \%$ and $22.54 \%$ for glass powder contents of $5 \%, 10 \%$ and $15 \%$ respectively. This increase in the V-funnel time indicates increase values of relative flow time and thereby the higher viscosity (resistance to flow) for the mixes.

4. The L-box value was also observed to follow an increasing trend with an average variation of $1.5 \%, 3.2 \%$ and $5 \%$ for glass powder contents of 5\%,10\% and $15 \%$ respectively.

5. The mechanical properties of SCC follow the inverse relations with the fly ash and glass powder contents for all grades of concrete.

6. The compressive strength of the mixes was observed that gradual increase with level of increase in glass powder contents. The average growth in compressive strength for all grades was around $6 \%, 15 \%$ and $20 \%$ for glass powder contents of $5 \%, 10 \%$ and $15 \%$ respectively.

7. The flexural strengths of the mixes were observed that gradual increase with level of increase in glass powder contents. The average growth in flexural strengths for all grades was around $2 \%, 3.7 \%$ and $6.75 \%$ for glass powder contents of $5 \%, 10 \%$ and $15 \%$ respectively.

8. From the above experimental results on mechanical properties for M20, M25 and M30 grade of SCC mix, it is clear that the percentage of replacement of glass powder is increases the strength is also increases gradually.

9. From the above mentioned work of various researchers and our present experimental work, it is clear that glass can be used as a replacement of fine aggregate in concrete because of its increased workability, strength parameters.

10. As disposal of waste by-products problem is a major problem in today's world due to limited landfill space as well as its escalating prices for disposal, utilization of waste glass in concrete will not only provide economy, it will also help in reducing disposal problems.

11. The results obtained from the present study shows that there is great potential for the utilization of best glass powder in concrete as replacement of fine aggregate. Due to cost effect we stopped at $15 \%$ of replacement of glass powder because it is more expensive for small quantity of work.

12. Considering the strength criteria, the replacement of fine aggregate by glass powder is feasible. Therefore we can conclude that the utilization of waste glass powder in concrete as fine aggregate replacement is possible.

\section{SCOPE OF THE FUTURE WORK}

From this experimental study it is clear indicated that using sugar cane bagasse ash in concrete increase strength. Following parameters will be study in future work:

1. The simplified mix design methodology was presented may be extended to the more number of concrete strength ranges. 
2. The investigations may be conducted with different mineral admixtures like Rice Husk Ash, Sugar cane Bagasse Ash and GGBS apart from fly ash.

3. To find out optimum amount of different types of mineral admixtures like Rice Husk Ash, Sugar cane Bagasse Ash, and GGBS that can be used in concrete for partially replacement of cement without significant loss of strength.

4. To check the various properties of concrete with variation of content of different types of mineral admixtures like Rice Husk Ash, Sugar cane Bagasse Ash, and GGBS.

\section{REFERENCES}

[1] Bouzoubaa N, Lachemi M. "Self-compacting concrete incorporating high volumes of class F fly ash: Preliminary results", Cement and Concrete Research, 2001, Vol.31, No.3, pp 413-420.

[2] EFNARC. "Specification and guidelines for self-compacting concrete", European Federation of Producers and Applicators of Specialist Products for Structures, 2002.

[3] EFNARC. "Specification and guidelines for self-compacting concrete", European Federation of Producers and Applicators of Specialist Products for Structures, May 2005.

[4] Jaya Shankar R, Hemalatha T, Palanichamy. K and Santhakumar. S, "Influence of fly ash and VMA on properties of self-compacting concrete", National Conference on Advances in materials and mechanics of concrete structures Department of Civil Engineering, IIT Madras, Chennai 12-13 August 2005, pp 25 - 32.

[5] Nan Su, Kung-Chung Hsub and His-Wan Chai. "A simple mix design method for self-compacting concrete". Cement and Concrete Research, 2001, Vol. 31, pp1799 - 1807.

[6] Okamura H, Ozawa K. "Mix design for self-compacting concrete". Concrete Library of Japanese Society of Civil Engineers, 1995, Vol. 25, No. 6, pp107-120.

[7] Okamura Hajime and Ouchi Masahiro. "Self - Compacting Concrete”. Journal of advanced concrete technology, 2003, Vol.1, No.1, pp 5 - 15.

[8] Subramanian, S. and Chattopadhyay D. "Experiments for mix proportioning of self-compacting concrete", The Indian Concrete Journal, 2002, pp.1320 .

[9] Okamura, H. Maekawa, K. Ozawa. "High-Performance Concrete", Gihodo Publishing, 1993.

[10] Jagdish Vengala and R. V. Ranganath, "Mixture Proportioning Procedures for Self-Compacting Concrete", the Indian Concrete Journal, August 2004, pp 13-20.

[11] Dr. N. Ganesan, Dr. P. V. Indira and Mr. P. T. Santosh Kumar, "Durability aspects of SCC”, The Indian concrete journal, May 2006.

[12] Okamura H., Ozawa K. and Ouchi M. "Self-Compacting Concrete”, Structural Concrete, March 2001, No. 1, pp 5-17.

[13] Jangid Jitendra B. and Saoji A.C. (2014) "Experimental investigation of waste glass powder as the partial replacement of cement in concrete production" IOSR Journal of Mechanical and Civil Engineering (IOSR-JMCE) e-ISSN: 2278-1684, p ISSN: 2320334X [International Conference on Advances in Engineering and Technology -(ICAET-2014)]

[14] Patel Dhirendra, Yadav R.K. and Chandak R.(2012) "Strength Characteristics of Cement Mortar Paste Containing Coarse and Fine Waste Glass Powder" International Journal of Engineering Sciences Research-IJESR Vol-03, Issue 02; ISSN: 2230-8504; e-ISSN-2230-8512 